DOI https://doi.org/10.30525/978-9934-588-46-4.07

\title{
LOCAL SELF-GOVERNMENT IN UKRAINE UNDER CONDITIONS OF DECENTRALIZATION: VECTOR OF DEVELOPMENT
}

\author{
Nepomnyashchyy O. M., Diegtiar O. A.
}

\section{INTRODUCTION}

Taking into account European-oriented vectors of social and economic integration, processes of democratization of Ukrainian society are a priority of development. In the context of unbalanced territorial development, an important aspect of ensuring the integrity and growth of the country's macroeconomic indicators is the identification of mechanisms for the realization of the potential of individual territories, which, taking into account the synergistic effect, will provide additional opportunities for the development of the state as a whole. Constitutional state should develop on the basis of ensuring constitutional rights and opportunities for every citizen through the development of civil society and the improvement of the effectiveness of the public administration system. Ukraine, having chosen the path of the leading European countries, has prioritized the processes of subsidiarity and decentralization management in the structure of the state, which has become the basis for the introduction of the reform of decentralization of power and territorial division. The establishment of a new type of territorial entities - amalgamated territorial communities - created additional opportunities for the development of the potential of individual territories, the formation of a socially active community, the creation of financial opportunities for the implementation of projects to ensure social and economic development in the field. The establishment of civil society institutions is intended to ensure the formation of a conscious, active and responsible community capable of forming its own proposals to ensure territorial development, implementing them and monitoring them at all stages of project implementation and financial support. The transfer of authority from central public administration to the field, which is the basis for the reform of decentralization of authority, provides the conditions for the formulation and adoption of management decisions of territorial development taking into account local specificities. And providing local communities with financial 
resources allows additional opportunities for macro and microeconomic growth.

Thus, the reform of decentralization of power was primarily aimed at building a human-centric approach to the management of territories, that is, the main tasks were the formation of a socially active community capable of improving its own indicators of social and economic development in order to increase the standard of living of the population in territories with different levels of initial development. The Ukrainian reform of decentralization of power was as the most effective of all the reforms that began after the events of the Revolution of Dignity, recognized by the European Community. Basis of its success is formation of new generation of local elite, leaders whose work is aimed at providing territorial development. The state creates conditions for integrated territorial communities to implement their own projects through the allocation of special powers and funding, and local communities realize their potential. At the same time, the problem of finding those local politicians who will have sufficient competence, knowledge, skills and management abilities in the new conditions of changing the system of public administration and economic management is relevant. After all, such politicians have faced fundamentally new tasks and challenges. Building an effective system of governance of the unified territorial community at the local level is a difficult and complex process, connected not only with the need for administrative influence and the creation of new mechanisms of financing and implementation of projects, but also with the formation of a new system of thinking, first of all, of the inhabitants of the community itself, without whose active participation it is impossible to effectively implement decentralization processes. Thus, the key tasks of continuing the implementation of decentralization processes are the normative, legal and organizational and administrative support of the realization of the potential of the territories by increasing the public participation of members of the public in ensuring social and economic development. As the experience of many developed countries has shown, the establishment of effective decentralization management mechanisms allows local self-government to reach a qualitatively new level of implementation of local development projects, which is important for community residents to understand their own participation in local development decisionmaking, common responsibility for these decisions and a sense of the results of such decisions through improvement of improving the standard of living in a certain territory. 


\section{Decentralization processes: national retrospective and world experience}

The history of decentralization processes has a number of contradictions in the search for a form of state administration of territories. Decentralization is a new perspective on the process of centralized governance in a state where independent territorial units are being established that form local autonomous governance systems, which requires the development of new approaches and governance mechanisms.

As experience shows, after the Revolution of Dignity in late 2013-early 2014, when Ukraine decided on the European vector of development, changes and adjustments were made to the stateadministrative practice of the Ukrainian state taking into account the requirements of those processes that began to take place: financial and political crisis, annexation of territory, separatism, unbalanced development of territories, destruction of old economic ties, necessity to ensure competitiveness of own production facilities.

The new stage of the implementation of public administration reform in Ukraine should be based on the principles of governance declared in the modern European model of public administration, since Ukraine has the goal of becoming a full member of the European community, and therefore should ensure its own competitive advantages precisely through the introduction of European Union norms and standards, including in the system of public administration and local selfgovernment as the basis of national and local development ${ }^{1}$.

In theoretical and practical research, the concept of "decentralization" is multidimensional and defined by authors through the use of different approaches. The word "decentralization" comes from the Latin language and means uncentralization, leaving the center, repeal of centralization ${ }^{2}$. So, it is a system of distribution of functions and powers between the levels of public administration and local self-government. In the context of decentralization of management, the processes of formation and development of the institution of local self-government are very

${ }^{1}$ Arabchuk Ya.I. Finansova detsentralizatsiia - osnovna skladova spromozhnoi hromady. Teoriia ta praktyka derzhavnoho upravlinnia $i$ mistsevoho samovriaduvannia. 2016. № 1. URL: http://nbuv.gov.ua/UJRN/ Ttpdu_2016_1_20.

${ }^{2}$ Sukharska L.V. Pravove rehuliuvannia finansovoho zabezpechennia rozvytku terytorialnyh hromad v Ukraini v umovakh biudzhetnoi detsentralizatsii. Derzhavne upravlinnia ta mistseve samovriaduvannia. 2016. № 3. S. 144-151. 
important. In other words, decentralization is a type of governance system where some central government functions are transferred to local governments ${ }^{3}$.

Ukraine followed the path of decentralization on April 1, 2014, when the Concept of Reforming Local Self-Government and Territorial Organisation of Power in Ukraine was approved. Adoption of this Concept was motivated by the following reasons:

- selection of the European integration vector of development and, as a result, the need to unify the system of public administration and local self-government with European practices;

-the unstable political situation and the influence of "old local elites" on the development of the state;

- the difficult political situation, the spread of recessionist sentiments, which was actively supported by pro-Russian local elites in the hope of gaining additional financial and political benefits on the ground;

- the imbalance of territorial development, which caused significant contradictions between different regions within the state and threatened the unity of the country;

- the need to rationalize and improve the efficiency of financing local development processes, which have been ineffective in the context of opacity and high corruption;

-the need to increase the social activity of the local population through participation in managerial decision-making and responsibility for their implementation;

- rationality of the transfer "to the field" of the priority of financing projects taking into account the specifics of the society 's own territorial potential.

As a result, the reform of decentralization of power in Ukraine was of high relevance and determined not only the effectiveness of social and economic development, but also the preservation of Ukrainian nationality at this difficult stage of the state.

Decentralization reform can be roughly divided into three blocks. The first block - territorial - is the boundary delimitation of the territory within which the society is formed, the assessment of territorial potential, the determination of the number of land resources and their functional purpose, the development of general plans of the territories and the

3. Drozdovska O.S. Teoretychni zasady finansovoi detsentralizatsii. Finansy Ukrainy. 2012. № 8. S. 19-25. 
determination of ways of managing land resources. The second block is financial - analysis of prospects and determination of proceeds from taxes and fees related to the territory of the respective administrative regional entity. The next block is the organizational conditions for ensuring the implementation of the powers of local self-government bodies (own and delegated from the center).

In addition, territorial communities have been able to cooperate by sharing land in the territories of different communities in order to combine their organizational capacities and resources for cooperation through joint programmes and the provision of more effective administrative services to the people of neighbouring territorial communities $^{4}$. For example, depending on the number of the population of the community, the degree of its socio-economic development, the industrial, agricultural direction, etc., cooperation can be carried out by centering the flows of the local population to the points of employment, obtaining social, cultural and domestic services to the centers of gravity of the communities bordering the analysed communities.

In general, the concept of decentralization has an ancient history. The problems of territorial development were addressed both during the ancient empires, the Middle Ages and in modern state formations. Historically, the question has been who to grant the right to collect taxes or make management decisions at the level of territorial development central or local authorities 5 .

The main objectives underlying decentralization should be defined as follows:

- delegation of powers from central executive bodies to the territorial community and distribution of financial resources;

- clear distribution of powers between executive authorities at the macro level and local self-government bodies at the local level;

-strengthening the responsibilities of local self-government bodies and officials to implement the decisions of voters and the Government.

\footnotetext{
${ }^{4}$ Melnychuk A., Ostapenko П. Detsentralizatsia vlady: reforma № 1 : analitychni zapysky. K. : TSOP “Hlobus” FOP Kravchenko Ya.O., 2016. 35 s.

${ }_{5}$ Korotych O. B. Kompleksnyi derzhavnyi mechanism upravlinnia rehionalnym rozvytkom Ukrainy. Dni nauky - 2008 : zb. tez dop., 23-24 zhovtn. 2008 r. : u 3 t. / red. kol. V.M. Oharenko ta in. ; Klasychnyi pryvatnyi universytet. Zaporizhia : KPU, 2008. T. 2. S. 32-33.
} 
The history of decentralization begins in the late nineteenth or early twentieth centuries. It was the result of economic changes, and includes the following four theories:

1. Decentralization ensures efficient resources allocation. A system in which decisions on the resources allocation in the public sector are taken at the regional and municipal levels, taking into account the opinion of the public, takes into account the local characteristics and social needs of territorial communities more fully.

2. Decentralization contributes to public responsibility for budgetary expenditures. The purpose of this argument is to ensure that taxes paid in the context of decentralization, public goods and services obtained in a more transparent manner, as well as the implementation of budgetary expenditures.

3. Existence of own tax base, regional and local possibilities for its expansion in order to promote regional and local economy.

4. Provision of regional and local governments the right to selfgoverning use of the budget, which encourages them to reduce irrational costs.

The most detailed issues of decentralization were investigated by J. Vedel. In his view, decentralization gives powers to non-governmental bodies and other bodies that are not hierarchically subordinate to state structures, especially those elected by the population ${ }^{6}$.

However, in foreign scientific legal literature, the distribution of powers to local self-government bodies from individual state authorities is often seen as a path of revolution rather than decentralization. Logic of decentralization is dual. First, decentralization has democratic advantages, and the development of democracy is much more real at the local level than at the national level. Second, decentralized management is more effective than centralized management for practical management objectives $^{7}$.

Delegating responsibility from the centre to the territories allows the public administration system to adapt its services to the needs of the population. The transition to decentralization is a kind of global change building a bottom-up democracy. Since the process of democratic development is very important, the priority is the awareness of citizens

\footnotetext{
${ }^{6}$ Vedel Dzh. Admynystratyvnoe pravo Frantsyy / per. s frants. L. M. Entyna. M.: Prohress, 1973. 512 s.

${ }^{7}$ Vedel Dzh. Admynystratyvnoe pravo Frantsyy / per. s frants. L. M. Entyna. M. : Prohress, 1973. 512s.
} 
about the activities of central and local authorities and the awareness of the authorities of the specific needs of the person in each individual territory, taking into account the peculiarities of the territory. Obviously, the easiest way to do this is at the basic level of local self-government, where citizens and their representatives are located.

A number of authors highlight different types of decentralization. We accumulate the data of the study by systematizing its results and presenting them in the form of a diagram (figure 1).

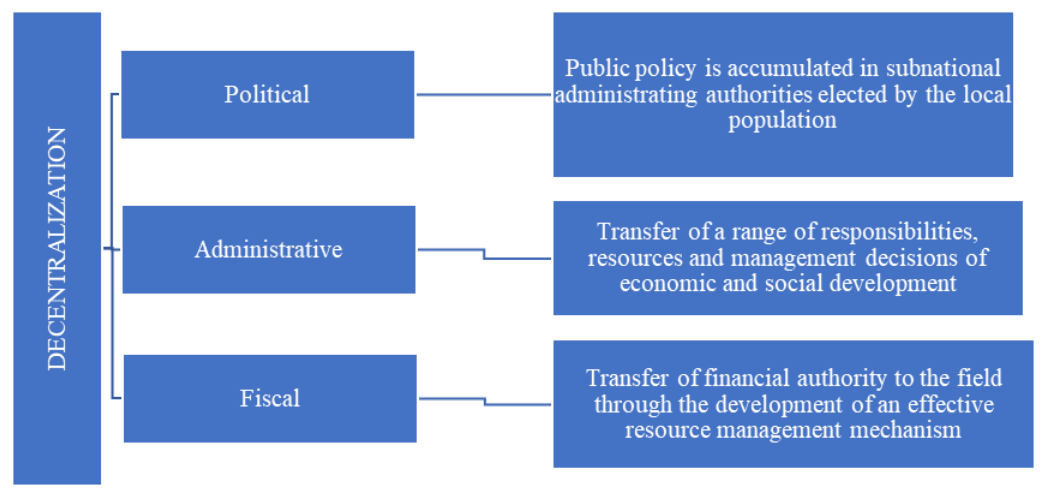

Fig. 1. Types of decentralization and their characteristics

Thus, a number of conclusions can be drawn from the analysis of the main approaches to defining decentralization:

1) the state may delegate part of the powers of the executive authorities to local self-government bodies decentralized within the limits of the law and in the interests of the local population;

2) decentralization of powers should take into account the principle of replacement of powers, that is, delegate powers to the level of power closest to a citizen, while being able to perform managerial functions more effectively than other authorities;

3) transfer of powers from the executive authorities provides for raising the level of local self-government in the system of state and regional authorities on granting the right to the local self-government body to make a decision on delegated powers on the basis of local characteristics ${ }^{8}$.

${ }^{8}$ Berezynskyi V.P. Rozvytok hromad u konteksti detsentralizatsii vlady v Ukraini. Naukovo-teoretychnyi almanakh “Hrani”. 2017. T. 20. № 1 (141). S. 48-54. 
Today, a great emphasis on the development of decentralization processes is placed on studying the world legislative, political, economic, legal experience in the development of local self-government and reforms of the regional organization of the authorities of the countries, taking into account their geographical, demographic, social and cultural conditions.

The basis of reforms of local self-government in Ukraine is the implementation of the provisions of the European Charter of Local SelfGovernment in national legislation. Special attention should also be paid to the analysis of the traditional decentralized systems of European countries. Based on the analysis of the features of the implementation of decentralization reform in countries such as Hungary, Poland, Latvia, Lithuania, Estonia, Czech Republic, Slovenia, Slovakia (which have many common features of socio-economic development and territorial particularities of the administrative structure, as well as Ukraine), the following key characteristics can be distinguished:

-defining the characteristics of the legislative, constitutional framework of administrative governance and the structure of local selfgovernment bodies;

- evaluation of local policies, decision-making methods and internal organization;

- defining the role of local self-government bodies in the provision of administrative and social services;

-development of money matters and financial administration mechanisms;

-finding ways to ensure competitive human-oriented economic development.

The process of decentralization of the system of powers in the countries of Central and Eastern Europe, as well as the Baltic states, is based on the principles of building a strong system of local selfgovernment, as a mechanism of transition to a strong state through the activation of civil society ${ }^{9}$.

Focusing on decentralization, European states have in one way or another faced the problem of improving their administrative and regional structures, but have approached it differently. Thus, some of them have implemented appropriate administrative and regional reforms, others

9 Nechyporenko A.V. Teoretychni aspekty biudzhetnoi detsentralizatsii mistsevoho samovriaduvannia $\mathrm{v}$ Ukraini. Naukovyi visnyk Uzhhorodskoho natsionalnoho universytetu. 2016. № 6 (2). S. 122-125. 
only partially replace some powers in the sphere of state policy from state bodies to local bodies. A problem for many European countries, in the context of decentralization or community autonomy, is the lack of adequate regional demographic and material resources to ensure effective governance and socio-economic development under the powers of local authorities, in particular the provision of adequate public (administrative) services, community security and the like. The consolidation of administrative and regional units in these countries began with the establishment of various regional forms of management ${ }^{10}$.

In recent years, the wave of decentralization that has passed from Central to Eastern Europe has gradually begun to reach not only developed countries, but also developing countries, providing them with additional opportunities to ensure their own competitiveness, improve the level of development of territories and improve the lives of the population. The transition of countries following the political tempest of 1989 and 1990 to decentralization processes involved the transformation of administrative functions, which in different European countries took place with varying intensity. In Poland, for example, this process took almost a decade. Hungary has undergone a transformation in less than a year. Internal economic systems had a significant influence on the course of transformation processes ${ }^{11}$.

Local self-government, which is an important sign of democracy in any state, has different forms and features in each particular political system. Only its purpose is unchanged in any political systems - the idea of using rational mechanisms of self-organization to solve the problem of direct interaction between people, individuals, regional community, authorities. It is impossible to solve the problems facing local selfgovernment bodies without coordination of their activities.

Regional development is an important component of decentralization processes by ensuring lower-level organization (community). The Law of the Italian Republic on the System of Local Autonomy, adopted in 1990, was aimed at optimizing the number of administrative and regional units, merging territories that do not have sufficient financial resources to

10 Skupchenko D.O. Normatyvno-pravove zabezpechennia rozvytku terytorialnykh hromad v Ukraini. Teoriia ta praktyka derzhavnoho upravlinnia. 2017. № 2. S. 1-7.

${ }^{11}$ Serohin S.M., Honcharuk N.T. Teoretychni zasady ta osnovni napriamky reformuvannia mistsevoho samovriaduvannia i detsentralizatsii vlady v Ukraini. Aspekty publichnoho prava. 2015. № 4. S. 111-120. 
solve current issues ${ }^{12}$. According to the law, new communes can be established in Italy if they have at least 10.000 inhabitants, the province - at least 200.000 inhabitants. The law also promoted the unification of communes with less than 5.000 inhabitants or their accession to large communes.

At the same time, the introduction of decentralization in France did not bring about a fundamental change in the maps of the administrative division. France 's current administrative regional structure is the result of the long evolution of the state under the influence of various factors. Since the second half of the 20th century, France has begun the process of decentralization of power, which is still ongoing, but the current regional structure has maintained its tradition since the 18th century. The reforms concerned mainly changes and partial expansion of the status of regional institutions. Regional authorities have been established for the purpose of land-use planning in the post-war period and are currently forming a policy of development of French settlements, ensuring even development of regions, including the most backward areas.

Obviously, with a large number of small administrative-territorial communities, the use of administrative powers in some areas requires cooperation between them. Therefore, municipal councils are quite common in France. The government may suspend the execution of decisions of city councils through its representatives - governors ${ }^{13}$. France has spent years discussing transformational processes to reduce the population of small rural settlements, sometimes home to only a few dozen people. However, public policy on this issue is thoughtful and not radical $^{14}$. There are no management decisions to merge the administrative units of a small rural area. However, the legislation includes various forms of social cooperation, the establishment of communities to use administrative powers, and the implementation of certain economic and social projects. The Law on Unification and Consolidation of Communes (June 16, 1971) provided for the possibility of unification of communes and the establishment of joint local self-

12 Vasyleva T.A. Reforma hosudarstvennykh institutov v Italii. Hosudarstvo i pravo. 1993. № 3. S. 133.

${ }^{13}$ Hanushchak Yu. Prefekty: uroky Frattsii dlia Ukrainy. K. : IKTS "Lehalnyi status", 2015. S. 5-42.

${ }^{14}$ Detsentralizatsiia publichnoi vlady: dosvid yevropeiskyh krain ta perspektyvy Ukrainy / O. Boryslavska, I. Zaverukha, E. Zakharchenko ta in. ; Shveitsarskoukrainskyi proekt "Pidtrymka detsentralizatsii v Ukraini" - DESPRO. K. : TOV "Sofiia", 2012. 128 s. 
government bodies in 1999, French communes received additional funding in accordance with amendments and additions to the legislative framework for the regulation of local self-government in the event of their active interaction. However, the problem of France's decentralized system is the unclear distribution of powers between public authorities and local self-government, which leads to the following problems:

- poor coordination of actions in the implementation of management functions in the public administration system,

- fragmentation of communes (36.000) and inconsistency in their coordination,

- difficulty in organizing the active participation of commune residents in the implementation of socio-economic development projects,

- uncoordinated work in different regions of social services, law enforcement services, road services, educational, health and other bodies performing social and economic support functions on the ground,

- problems of urban planning regulation.

More than $80 \%$ of communes in France are small (up to 1.000 inhabitants), and $98 \%$ of communes have up to 10.000 inhabitants. This fact significantly limits the ability of these communes to financially support the implementation of their own development projects, and even limits the amount of state support for such projects in the system of municipal subsidies and local taxes ${ }^{15}$.

There are three types of settlements in rural France: small towns (less than 20.000 people), cities - shopping centres (1000-15000 people), small villages (less than 1000 people). Small villages, due to their territorial and demographic characteristics, do not have sufficient resources, infrastructure to be able to obtain the quality administrative services that communes must provide. This problem is solved in two ways: first, neighbouring large communities provide a wide range of services to the population of small villages, using their own infrastructure (schools, hospitals, supermarkets, educational and cultural institutions, etc.); secondly, public authorities provide financial support to small rural communities through financial mechanisms to regulate local financing ${ }^{16}$.

15 Hladii V.I. Reformuvannia systemy mistsevoho samovriaduvannia: dosvid Vyshehradskoi hruppy. Hrani. 2015. № 12 (1). S. 57-63. URL: http://nbuv.gov.ua/ UJRN/Grani_2015_12\%281\% 29_12.

${ }^{16}$ Hanushchak Yu. Prefekty: uroky Frattsii dlia Ukrainy. K. : IKTS "Lehalnyi status", 2015. S. 5-42. 
In France, the issue of consolidation of communes has been repeatedly raised, but no radical measures have been taken. On the other hand, the government has taken various measures to promote commune cooperation, including financial support. As a result, France is beginning to establish "united communes", which had various forms and legal status. To this end, the Act on the Organization of Processes of Decentralization of Power in 1999 gave such communities a special legal status and created favourable opportunities to attract funds through the local taxation system. As a result of the reform, 14 metropolitan districts, 120 agglomerations and 2.033 united communes were established until 1 January 2002. In general, such communities cover the $75 \%$ of the French population $^{17}$.

The proposed instrument for the reorganization of communes in France aims to reduce the number of municipalities by:

- merging urban municipal communities with a population of $>15.000$ inhabitants and achieving the internal balance of urban territorial division;

-increasing the average population of the French community to 1750;

- developing local democracy and supporting local public services.

- meeting the needs of urbanization.

The Government of France has developed financial mechanisms to stimulate the consolidation of communes, a three-year financial deal to provide state grants to new municipalities with more than 10.000 inhabitants, which was the result of the unification of more than 300 municipalities ${ }^{18}$.

The success of reform in France depends on the successful addressing such challenges:

-the impact of the merger of communes on the formation and strengthening of new territorial communities;

-special support is directed to regions which compete on the level of economic development;

${ }^{17}$ Hanushchak Yu. Prefekty: uroky Frattsii dlia Ukrainy. K. : IKTS "Lehalnyi status", 2015. S. 5-42.

${ }_{18}$ Detsentralizatsiia publichnoi vlady: dosvid yevropeiskyh krain ta perspektyvy Ukrainy / O. Boryslavska, I. Zaverukha, E. Zakharchenko ta in. ; Shveitsarskoukrainskyi proekt "Pidtrymka detsentralizatsii v Ukraini" - DESPRO. K. : TOV "Sofiia", 2012. $128 \mathrm{~s}$. 
- priority on sustainable and balanced development of both megacities and remote country areas ${ }^{19}$.

In addition, the reform provides for the strengthening of the participation of citizens in the social and economic development of the territories. It includes:

-informing citizens about the possibility of decentralization and their participation in management decisions on territorial development format of public participation in France - public debate (CNDP);

- citizens "participation in the development of environmental policies and the implementation of projects within the framework of national interests with significant environmental and socio-economic consequences;

- citizens 'participation in the design, implementation and evaluation of activities, which affects society through the establishment of councils at the appropriate level;

-facilitating the citizens 'participation in ensuring the powers of local self-government by exchanging information and ensuring their interests in all government bodies, providing opportunities for proposals and initiatives concerning the needs of citizens;

- organization of local referendums, where citizens can determine the fate of local projects, public initiatives, discussion of municipal development activities ${ }^{20}$.

New Law on the Regional System of the Republic of August 7.2015 defines:

- strengthening inter-municipal ties;

-reorientation of communities towards regional social security cooperation;

- giving the regions greater authority and management, priority to economic development and land-use planning ${ }^{21}$.

${ }^{19}$ Detsentralizatsiia publichnoi vlady: dosvid yevropeiskyh krain ta perspektyvy Ukrainy / O. Boryslavska, I. Zaverukha, E. Zakharchenko ta in. ; Shveitsarskoukrainskyi proekt "Pidtrymka detsentralizatsii v Ukraini" - DESPRO. K. : TOV "Sofiia", 2012. $128 \mathrm{~s}$.

${ }^{20}$ Detsentralizatsiia publichnoi vlady: dosvid yevropeiskyh krain ta perspektyvy Ukrainy / O. Boryslavska, I. Zaverukha, E. Zakharchenko ta in. ; Shveitsarskoukrainskyi proekt 'Pidtrymka detsentralizatsii v Ukraini' - DESPRO. K. : TOV "Sofiia", 2012. $128 \mathrm{~s}$.

${ }^{21}$ Detsentralizatsiia publichnoi vlady: dosvid yevropeiskyh krain ta perspektyvy Ukrainy / O. Boryslavska, I. Zaverukha, E. Zakharchenko ta in. ; Shveitsarsko- 
Strengthening decentralization processes in France involves improving social activities, including important non-material measures, new forms of governance to address local problems, long-term support in the areas of project ownership, consistency of management actions, integration, regulation and capacity to respond to environmental threats, emergencies.

The aim of the decentralization reform in Slovakia is to promote a collective exchange of experiences between the public and private sectors in the system of a unitarian parliamentary republic. Slovakia has been a full member of the European Union since 1 May 2004 and a member of the V4 Visegrad Countries (Poland, Hungary, Czech Republic, Slovakia). Today Slovakia (which accumulated the experience of decentralization of the countries of the V4 Visegrad Countries) has a two-tier administrative and regional system of separation of powers consisting of eight regions and 79 territorial communities. Local government reforms have been ongoing in Slovakia for a long time. The reforms have some implementation problems, as the decentralization project did not have the support of the majority of the country 's political forces. The first concept of decentralization reform was approved by the Government in 2000. The country did not consider this concept within the Slovak National Council, because officials were not sure that the concept would be supported by the opposition and some coalition partners. Thus, the government assumed responsibility for the reform of decentralization, which was based on the three pillars of the modernization of public administration:

-Firstly, the transfer of powers to the level of local self-government was envisaged with the introduction of the principles of financial decentralization, preparation of systemic changes in the field of health, education, social sphere, culture and transport;

-Secondly, the regional reform that forms the second - local level of self-government thus solved problems of organization or unification of small settlements;

- Thirdly, the administrative reform that has led to the restructuring of public administration by developing an electoral system with appropriate mechanisms for the selection of local self-government and the principles,

ukrainskyi proekt "Pidtrymka detsentralizatsii v Ukraini" - DESPRO. K. : TOV "Sofiia", 2012. 128 s. 
laws and regulations inherent in European Union public administration systems $^{22}$.

This concept became the basis of a political agreement between the parties of representatives of the ruling coalition, local self-government (association of cities and towns) and public communities. In 2001, differences among members of the ruling coalition in Parliament regarding the concept of reform of Slovakia's administrative and territorial structure led to a split in the government. The new government was created immediately after the 2002 elections, and it began a process of fundamental decentralization of power.

In general, the steps taken to reform the decentralization of power in Slovakia can be defined as follows:

-1998 - The Slovak Government endorses the concept of decentralization, which has become the main document for the redistribution of powers, responsibilities and budgets between the state and regional communities;

-2002 - The second elected regional level of self-government based on the concept of public administration reform was introduced; in December, the Slovak National Council adopted a policy statement on reforms of local self-government and decentralization of state power;

-2003-2004 - was approved the project "Introduction of decentralization of state power"; in May 2003, the Slovak Parliament approved the "Project for Decentralization of State Authority for 20032006", which became the basis for the preparation and implementation of relevant legislative decisions to strengthen the rights and capacities of local self-government; almost 400 central government powers were transferred to the local human settlements level;

-On 1 January 2005, a new system of local self-government financing, financial decentralization, was introduced.

The Constitution of the Slovak Republic, adopted in 1992, defined society as the basis of self-government. In general, local self-government consists of communities - legal communities that independently manage their property and their own financial resources. Also, the Constitution

${ }^{22}$ Hladii V.I. Reformuvannia systemy mistsevoho samovriaduvannia: dosvid Vyshehradskoi hruppy. Hrani. 2015. № 12 (1). S. 57-63. URL: http://nbuv.gov.ua/UJRN/Grani_2015_12\%281\% 29_12. 
defines the right of one community to interact with other communities to ensure common interests ${ }^{23}$.

After the completion of the administrative and territorial reform, local self-government bodies with new powers were formed in about three thousand settlements (cities and villages), and 8 districts divided into 79 regions were created. There were 2.891 communities in the districts, 130 of them were urban and others rural. Rural communities were divided into cadastral zones ${ }^{24}$.

Thus, decentralization of power is highly relevant and is actively developing in many developed countries with broad market liberalization, privatization and priority on reforms to improve the social and economic security of the population. The reform of decentralization is based on a single principle, which determines the need for delegation of authority from central authorities to the field in order to improve the management of the production of goods and services, social security and the solution of problems of territorial development ${ }^{25}$. The motivation for decentralization has changed over the past two decades. EU countries have become more decentralized, some countries have implemented reforms that have significantly changed the institutional structure of financial decentralization. The motivation for decentralization varies from country to country according to the degree of implementation of the reform and the depth of its implementation. In general, the reasons for the development of decentralization processes in different countries may be as follows:

-democratic/political motivation: Eastern European countries underwent waves of decentralization in 2000, 2004 and 2006: Poland, Slovakia, Czech Republic, Estonia, Hungary, related to political crises;

- economic/budgetary motivation: Greece, Italy, Portugal - countries struggled with problems of declining living standards and unbalanced socio-economic development.

23 Hladii V.I. Reformuvannia systemy mistsevoho samovriaduvannia: dosvid Vyshehradskoi hruppy. Hrani. 2015. № 12 (1). S. 57-63. URL: http://nbuv.gov.ua/UJRN/Grani_2015_12\%281\% 29_12.

24 Hladii V.I. Reformuvannia systemy mistsevoho samovriaduvannia: dosvid Vyshehradskoi hruppy. Hrani. 2015. № 12 (1). S. 57-63. URL: http://nbuv.gov.ua/UJRN/Grani_2015_12\%281\% 29_12.

25 Tarasenko T. Problema detsentralizatsii v reformuvanni mistsevoho samovriaduvannia v Ukraini. Derzhavne upravlinnia ta mistseve samovriaduvannia. 2014. № 2. S. 277-286. 
For Ukraine, both reasons for decentralization are relevant in the context of political instability, economic crisis and low social security for the population and the unarmonic development of the territories. Tiered governance reforms are becoming increasingly contextual and can be presented in three interrelated dimensions: institutional, regional and public administration. In this context, the transition to multilevel governance to create an effective system of influence in the regions that will ensure their sustainable development in countries is crucial.

\section{Conceptual framework for reform of local self-government in conditions of decentralization in Ukraine}

The reform of decentralization in Ukraine to increase the powers of local self-government is a long-awaited response of the state to the demand in society for the development of a new ideology of administrative management, the formation of a renewed culture of public administration, the readiness of state officials and local elites to make decisions in the context of increased mobility and the specification of local development decision-making and personal responsibility for the implementation of these decisions in practice. Undoubtedly, the reform of local self-government will not be successful without improving the administrative and regional structure of the state. In accordance with Cabinet of Ministers Decision No. 333-p of April, 1, 2014, Ukraine approved the Concept of Reform of Local Self-Government and Regional Organization of Power. The purpose of the concept was to define certain aspects and conditions for the implementation of mechanisms of effective local self-government and regional organization of power for the creation and maintenance of a adequate living environment for citizens, the provision of quality and accessible public services, the creation of institutions of direct democracy, in accordance with the interests of citizens in all spheres of life ${ }^{26}$.

The reform of decentralization in Ukraine provides for the establishment of administrative and territorial units at the level of local communities, which are independent and self-sufficient social communities that can protect their rights and interests by participating in

26 Tarasenko T. Problema detsentralizatsii v reformuvanni mistsevoho samovriaduvannia v Ukraini. Derzhavne upravlinnia ta mistseve samovriaduvannia. 2014. № 2. S. 277-286. 
the solving of local problems through the organizational and financial autonomy of communities and local self-government bodies ${ }^{27}$.

The concept defines that due to the considerable fragmentation of regional communities in Ukraine, local autonomous governments of such communities are in fact unable to exercise the powers granted to them by law. Improving the regional organizational system of public administration is necessary to improve the management of public development in the region. Support for the disproportionate administrative and regional structure as the basis of the existence of an irrational regional power organization (absence of a full-fledged administrative and regional unit of the basic level, existence of a territorial community of the village, settlement, territory of the city or other administrative and territorial unit within another regional community, the city) leads to a conflict of competences between local self-government bodies and local executive authorities. We will determine how to optimize the system of power allocation within the framework of the Concept of Decentralization of Power at the national, regional and local levels (figure 2).

Within the framework of decentralization processes, an important element of reform is the distribution of powers between authorities at various levels and local self-government bodies. It is unacceptable to duplicate the functions and exercise of powers by several authorities, as this leads to a decrease in the efficiency of the management system, and to the non-consistency of management processes. We will define the system of powers of various state, regional authorities and territorial communities within the framework of the Concept of Decentralization of Power (figures 3, 4).

27 Vorona P.V. Mistseve samovriaduvannia i politychni partii v Ukraini : monohrafiia. Kh. : Vyd-vo KharRI Nadu «Mahistr», 2008. 184 s. S. 54. 
Legislative enforcement of decentralization processes - legal capacity of local communities to exercise their own powers

Subsidiarity - attribution of central authority to bodies, which are in direct contact with communities

Avoiding duplication of management functions by different authorities

Community transparency and accountability

Organizational and economic support for the activities of territorial communities

Financial arrangements for real self-government

Optimization of the public administration system to improve the quality and availability of administrative services

Mechanisms for monitoring socio-economic functions and administrative services

Democratization, increased social activity, involvement of local residents in management decisions and responsibility for their implementation

Fig. 2. Concepts of decentralization of power in Ukraine at the national, regional and local levels 


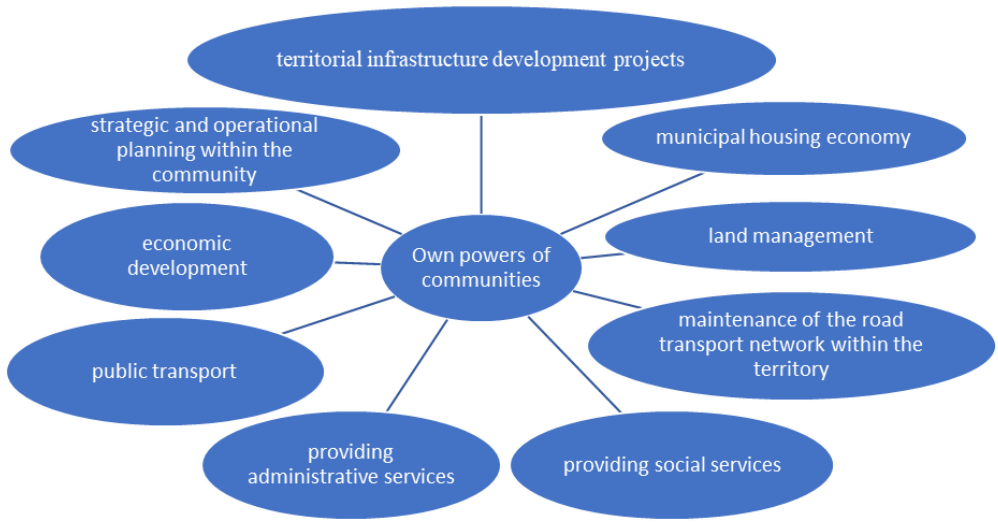

Fig. 3. Communities own powers in accordance with the Concept of Decentralization of Power in Ukraine

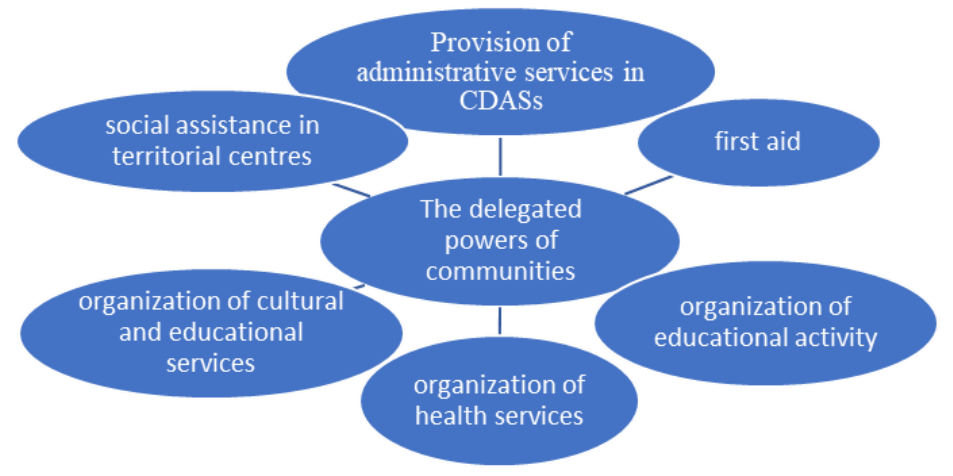

Fig. 4. Delegated powers of communities in accordance with the Concept of Decentralization of Power in Ukraine

The normative and methodological framework for building the future model of sustainable development of administrative and regional units is set out in the international standards for building smart systems "Smart 87". Currently, the state authority in Ukraine has four options for developing further actions. First, the country should change the administrative and regional structure of the district level, the second - to minimize the options of the possibility of uniting all communities within 
the existing district, the third - to continue the development of the legal framework for ensuring decentralization processes, the fourth - to unite the territories of two or more adjacent districts for a new territorial association $^{28}$. Comprehensive integration of a wide range of technological, general technical, design, organizational-management and logistics solutions, SMART architecture into the system of legislative support of decentralization processes provides an effective information and analytical basis for continuation of processes of community development, creation of opportunities for their interaction and provides additional functions of control of transparency of projects implementation both at the level of public administration and at lower levels of the hierarchy of the system. At the same time, standards defining common principles for designing and building a community network create the conditions for the formation of a new model of regional power organization and administrative and regional structure related to the development and implementation of public policies, taking into account European approaches to the management of social, industrial, residential and social services. The development of evaluation indicators, the determination of appropriate conditions for the development of competitiveness, the deepening of horizontal and vertical ties on the basis of the introduction of regulatory regulation of the technical parameters of the network infrastructure for the development of territories, the legal basis of local self-government, the integration of efforts of local business structures and the public, the transformation of the system of state regulation are important tasks of further decentralization of power in Ukraine ${ }^{29}$. Organization of the system of management of amalgamated territorial community at the level of central and local authorities and local self-government bodies, coherence of strategic goals of regional development and innovation, public-private partnership, synchronization of territorial development activities at different management levels and search for effective ways of realization of existing potential of territories are basic principles of social economic

28 Vorona P.V. Mistseve samovriaduvannia i politychni partii v Ukraini : monohrafiia. Kh. : Vyd-vo KharRI Nadu «Mahistr», 2008. 184 s. S. 54.

${ }^{29}$ Dosvid detsentralizatsii u krainah Yevropy: zb. dok. Per. z inoz. mov / Zah. red. V.B. Hroismana. K. : Instytut zakonodavstva Verhovnoi Rady Ukrainy, 2015. 766 s. 15 . Yevropeiska hartiia mistsevoho samovriaduvannia ta rozvytok mistsevoi I rehionalnoi demokratii v Ukraini : naukovo-praktychnyi posibnyk / Uporiad. O.V. Beiko, A.K. Huk, V.M. Kniaziev ; Za red. M.O. Pukhtynskoho, V.V. Tolkovanova. K. : Kramar, 2003. 396 s. 
development of society. The strategic direction of operational activities based on the development of a unified state policy on the needs of regional development, concentration of resources, regulation of technical aspects is a system of assessment and planning of ways to realize the resource potential of the territory in order to maximize the benefits of their use by community ${ }^{30}$.

Strengthening the competitiveness of the territories through the implementation of the above-mentioned tasks will provide an opportunity to find and work on the mutual interests of Ukraine and the EU in the implementation of key infrastructure projects related to ensuring the competitiveness of the territories. It is technical regulation and national standardization in accordance with the requirements of the European economic space that is the organizational and technical basis of the economic and scientific and technical cooperation of the amalgamated territorial community in the formation of infrastructure interaction networks and the result of the objective need to manage technical and economic processes in the regions ${ }^{31}$.

In the context of the implementation of decentralization reform, disassociation from the model of central power in the country, the ability of local self-government to create an effective system of regional organization in Ukraine were approved by the Presidential Decree in the Strategy for Sustainable Development of Ukraine until 2020 and the European Charter of Local Self-Government, decentralization fully conforms to the provisions and principles of self-sufficiency of selfgovernment of the territories. The transformation of the system of local self-government demonstrates Ukraine 's intention to establish a system of territorial development in accordance with European principles ${ }^{32}$.

${ }^{30}$ Mistseve samovriaduvannia $\mathrm{v}$ umovakh detsentralizatsii vlady $\mathrm{v}$ Ukraini : Kolektyvna monohrafiia / Kol. avt. ; za zah. red. R.M. Pliushcha. K. : RIDNA MOVA, 2016. 744 s.

${ }^{31}$ Dosvid detsentralizatsii u krainah Yevropy : zb. dok. Per. z inoz. mov / Zah. red. V.B. Hroismana. K. : Instytut zakonodavstva Verhovnoi Rady Ukrainy, 2015. 766 s.; Yevropeiska hartiia mistsevoho samovriaduvannia ta rozvytok mistsevoi I rehionalnoi demokratii v Ukraini. Naukovo-praktychnyi posibnyk / Uporiad. O.V. Beiko, A.K. Huk, V.M. Kniaziev ; Za red. M.O. Pukhtynskoho, V.V. Tolkovanova. K. : Kramar, 2003. P. 3.

${ }^{32}$ Mistseve samovriaduvannia $\mathrm{v}$ umovakh detsentralizatsii vlady $\mathrm{v}$ Ukraini : Kolektyvna monohrafiia / Kol. avt.; za zah. red. R. M. Pliushcha. K. : RIDNA MOVA, 2016. 744 s. 
Ukraine supports global trends in improving national security, as well as the establishment in the legislation of a financial and political framework to increase the transparency of territorial development and expenditures of budgets at different levels in the context of Ukraine's gradual integration into the European space. Within the framework of cooperation between Ukraine and the EU in the context of the abandonment of energy resources of the Russian Federation, the construction of an energy-efficient system at the level of individual territories is an important issue. Compliance with the obligations of the Association Agreement between Ukraine and the EU and the Energy Community provides for a gradual transition from traditional technologies to fundamentally new renewable energy solutions capable of providing electricity transmission, storage and conversion services. In this respect, not only national electricity systems will play an important role, but also projects for energy modernization of integrated territorial communities, without which the country may find itself in a black-out environment due to the inability to finance its own energy needs. In this regard, the strategic decision for community development is the creation of a new intellectual infrastructure, which is inextricably linked to the development of an information infrastructure suitable for technical and managerial objectives for sustainable economic functioning and development ${ }^{33}$. Technical and technological processes for community development shall be in accordance with the provisions of the International Organization for Standardization, ISO, the International Electrical Committee (IEC), the International Telecommunication Union (ITU) and other organizations ${ }^{34}$. On the basis of standardized processes in the EU, a future functional European information system is conceptually modeled, which would allow domestic businesses and enterprises, in particular in the field of electricity, to compete in European markets.

Automation of infrastructure support processes as a trend of development of territories in the world in the 1920s, can be the next step to increase the efficiency of decentralization processes in Ukraine. An

33 Roesel F. Do mergers of large local governments reduce expenditures? Evidence from Germany using the synthetic control method. European Journal of Political Economy. 2019. № 50 (1). P. 22-36.

34 Roesel F. Do mergers of large local governments reduce expenditures? Evidence from Germany using the synthetic control method. European Journal of Political Economy. 2019. № 50 (1). P. 6. 
example of the advantages of standardizing and harmonizing energy supply processes in accordance with world norms and standards was given above, which can enable amalgamated territorial community, through their own energy efficiency, to withdraw free funds for other infrastructure or social projects.

The legal and methodological framework for the successful development of sound territorial management systems is set out in the International Smart Grid Standards BSI (British Standards Institute), as a result of which, the world 's first PAS 1812014 Smart City system was introduced in London for practical planning of urban development in the UK. The study, which has more than 100 SC \& C standards, is available at three levels: strategic, technical, and process standardization. Technical standards indicate "what to do" in terms of introducing and/or operating a reasonable territory management model. Process standards are mainly related to issues on which strategic standards need to be based. The strategic level implies the formation of forward-looking plans by understanding the set of standards and technical solutions necessary for implementation at different stages of territory development ${ }^{35}$. This system of smart management can be introduced to solve issues of transport, water quality, social protection of older persons and other social issues, involves the transformation of the territory into a digital metropolis.

So, the Ukrainian experience of reform of decentralization of power is quite successful. The international community has recognized decentralization reform as one of the most successful in Ukraine in recent times. Within the framework of the European integration vector, the development of national systems to ensure the competitiveness of territories requires the state to create conditions for the implementation at the territorial level of the standards and provisions of the main European documents. Also, in the context of active processes of digital transformation, the authorities in Ukraine face a new task of providing information and analytical support and automation of processes of socioeconomic development of the territories taking into account the prospects of cooperation at the national and pan-European levels. Digitalization processes are an integral part of modern reasonable sustainable

35 Roesel F. Do mergers of large local governments reduce expenditures? Evidence from Germany using the synthetic control method. European Journal of Political Economy. 2019. № 50 (1). P. 12-13. 
development of cities and territories, that is, these aspects can be defined as prospects for further development of decentralization processes.

\section{CONCLUSIONS}

In 2014, Ukraine embarked upon a reform of decentralization of power, the effectiveness of which is evidenced by the best practices of developed countries of the world. Ukraine, in implementing the main provisions of the Cooperation Agreement with the European Union, has identified the state of local self-government as one of the development priorities. At the moment, the concentration of efforts of state and local authorities on the introduction of a course of European integration taking into account the tasks of local development has produced results through the formation of real foundations for the development of regional democracy. As our European colleagues note, decentralization is one of the most successful reforms for today, which is being effectively implemented in the country. The reform of decentralization in a broad sense involves the transfer of a number of managerial powers from the central authorities "to the field" and enhances the financial capacity of territorial communities. The practices of the leading European countries show that the reforms of decentralization of power have been carried out in the light of political or economic challenges. For Ukraine today, both problems are relevant to ensure sustainable national and regional development. European countries have carried out reforms of the administrative and territorial structure, despite their specificity and conditions of territorial development. The main reasons for the reforms were the imbalance in the development of the territories and the inefficient system of providing services to the population of the remote territories. At the same time, each European country solved these issues differently. Some countries have moved to the policy of consolidation of territorial communities, some have taken the path of motivating cooperation between the united territories to ensure social and economic development. Any transformation process was based on financial and organizational impact mechanisms. An important aspect of the development of territories in the context of decentralization was the social activity of the local population, the increase of which was intended through the involvement of local residents to the management decisions on territorial development and joint responsibility for their implementation. In general, the reforms of decentralization of power, which include increased powers and opportunities to ensure the own development of local communities, have been successful and can be 
taken for analysis and development of proposals for implementation into Ukrainian practice.

Decentralization in Ukraine includes processes of distribution of functions, powers, financial resources and responsibilities between the central and local levels in order to improve the management of local budgets, as well as ensuring regional development and social security of the population. Today Ukraine needs to carry out reforms, first of all, in the system of administrative and regional structure of power to increase the efficiency of the activities of local self-government bodies. These processes require more than just a renewal of the structure, it is the transformation of state mechanisms that is necessary. The establishment of decentralization processes is an important factor in ensuring the effectiveness of public administration, especially its legal and organizational and functional components. However, a number of pressing issues of territorial development remain unresolved: creation of jobs, intensification of entrepreneurial activity, social security, increase of labor productivity in remote territories and others. Among the promising areas of decentralization of power in Ukraine are the processes of information and analytical support, digitalization and standardization of management and socio-economic processes. It is important in today 's world to build a "smart" territory - a space that is comfortable and safe for use by the local population, which automatically determines the possibilities of maximum rational use of available resources and mobile response to challenges and changes in the external environment. Thus, the further development of decentralization processes will ensure the competitiveness of territories in the European economic space, will allow for more effective use of local resources in order to ensure the socioeconomic development of communities.

\section{SUMMARY}

The processes of building a developed state require more than simply updating or improving the elements of public administration, and changes in public administration are necessary, particularly with regard to the legal and institutional management of decentralization, which is an important factor in ensuring the effectiveness of public administration. The study identified the need to introduce democratic reforms in the country related to the change of social participation in the processes of territorial development in general. The reform of decentralization in Ukraine should be based on the redistribution of powers between government levels and the decentralization of public administration to 
change relations between citizens and authorities. This is a necessary condition - to establish effective interaction between the central and regional authorities and local self-government bodies. The practice of the leading European countries demonstrates the economic and political prerequisites for decentralization processes. World practices reveal the length of the processes of decentralization of power. Some countries are moving towards the consolidation of territorial units, fundamentally changing the administrative boundaries of territorial communities. Other countries are forming a more effective regional policy by motivating administrative and territorial units to cooperate and jointly implement socio-economic development projects. However, both concepts bring real practical results increasing the main indicators of provision of administrative, social services and comfort of life of the population, despite the distance of their place of residence from large centers of attraction of the population. For Ukraine, these problems are equally relevant. Thus, decentralization development processes are also highly relevant. Promising directions for further reforms are information and analytical support of processes of development of local communities, digitalization and automation of processes of social and economic support of local population with the aim of formation of "smart" territorial space, which will increase comfort of population life and ensure sustainable balanced development of territories.

\section{REFERENCES}

1. Arabchuk Ya.I. Finansova detsentralizatsiia - osnovna skladova spromozhnoi hromady. Teoriia ta praktyka derzhavnoho upravlinnia $i$ mistsevoho samovriaduvannia. 2016. № 1. URL: http://nbuv.gov.ua/ UJRN/Ttpdu_2016_1_20.

2. Sukharska L.V. Pravove rehuliuvannia finansovoho zabezpechennia rozvytku terytorialnyh hromad $\mathrm{v}$ Ukraini $\mathrm{v}$ umovakh biudzhetnoi detsentralizatsii. Derzhavne upravlinnia ta mistseve samovriaduvannia. 2016. № 3. S. 144-151.

3. Drozdovska O.S. Teoretychni zasady finansovoi detsentralizatsii. Finansy Ukrainy. 2012. № 8. S. 19-25.

4. Melnychuk A., Ostapenko П. Detsentralizatsia vlady: reforma № 1 : analitychni zapysky. K. : TSOP "Hlobus" FOP Kravchenko Ya.O, 2016. $35 \mathrm{~s}$.

5. Korotych O.B. Kompleksnyi derzhavnyi mechanism upravlinnia rehionalnym rozvytkom Ukrainy. Dni nauky - 2008 : zb. tez dop., 23-24 zhovtn. 2008 r. : u 3 t. / red. kol. V.M. Oharenko ta in. ; 
Klasychnyi pryvatnyi universytet. Zaporizhia : KPU, 2008. T. 2. S. 32-33.

6. Vedel Dzh. Admynystratyvnoe pravo Frantsyy / per. s frants. L.M. Entyna. M. : Prohress, 1973. 512 s.

7. Berezynskyi V.P. Rozvytok hromad u konteksti detsentralizatsii vlady v Ukraini. Naukovo-teoretychnyi almanakh "Hrani". 2017. T. 20. № 1 (141). S. 48-54.

8. Nechyporenko A.V. Teoretychni aspekty biudzhetnoi detsentralizatsii mistsevoho samovriaduvannia v Ukraini. Naukovyi visnyk Uzhhorodskoho natsionalnoho universytetu. 2016. № 6 (2). S. $122-125$.

9. Skupchenko D.O. Normatyvno-pravove zabezpechennia rozvytku terytorialnykh hromad $\mathrm{v}$ Ukraini. Teoriia ta praktyka derzhavnoho upravlinnia. 2017. № 2. S. 1-7.

10. Serohin S.M., Honcharuk N.T. Teoretychni zasady ta osnovni napriamky reformuvannia mistsevoho samovriaduvannia i detsentralizatsii vlady v Ukraini. Aspekty publichnoho prava. 2015. № 4. S. 111-120.

11. Vasyleva T.A. Reforma hosudarstvennykh institutov $\mathrm{v}$ Italii. Hosudarstvo i pravo. 1993. № 3. S. 133.

12. Hanushchak Yu. Prefekty: uroky Frattsii dlia Ukrainy. K. : IKTS "Lehalnyi status", 2015. S. 5-42.

13. Detsentralizatsiia publichnoi vlady: dosvid yevropeiskyh krain ta perspektyvy Ukrainy / O. Boryslavska, I. Zaverukha, E. Zakharchenko ta in. ; Shveitsarsko-ukrainskyi proekt "Pidtrymka detsentralizatsii V Ukraini" - DESPRO. K. : TOV "Sofiia”, 2012. 128 s.

14. Hladii V.I. Reformuvannia systemy mistsevoho samovriaduvannia: dosvid Vyshehradskoi hruppy. Hrani. 2015. № 12(1). S. 57-63. URL: http://nbuv.gov.ua/UJRN/Grani_2015_12\%281\% 29

15. Tarasenko T. Problema detsentralizatsii $\mathrm{V}$ reformuvanni mistsevoho samovriaduvannia v Ukraini. Derzhavne upravlinnia ta mistseve samovriaduvannia. 2014. № 2. S. 277-286.

16. Vorona P. V. Mistseve samovriaduvannia i politychni partii $\mathrm{V}$ Ukraini : monohrafiia. Kh. : Vyd-vo KharRI Nadu "Mahistr", 2008. 184 s.

17. Dosvid detsentralizatsii u krainah Yevropy : zb. dok. Per. z inoz. mov / Zah. red. V.B. Hroismana. K. : Instytut zakonodavstva Verhovnoi Rady Ukrainy, 2015. 766 s. ; Yevropeiska hartiia mistsevoho samovriaduvannia ta rozvytok mistsevoi I rehionalnoi demokratii $\mathrm{v}$ Ukraini. Naukovo-praktychnyi posibnyk / Uporiad. O.V. Beiko, 
A.K. Huk, V.M. Kniaziev ; Za red. M.O. Pukhtynskoho, V.V. Tolkovanova. K. : Kramar, 2003. 396 s.

18. Mistseve samovriaduvannia $\mathrm{v}$ umovakh detsentralizatsii vlady $\mathrm{v}$ Ukraini : Kolektyvna monohrafiia / Kol. avt. ; za zah. red. R. M. Pliushcha. K. : RIDNA MOVA, 2016. $744 \mathrm{~s}$.

19. Roesel F. Do mergers of large local governments reduce expenditures? Evidence from Germany using the synthetic control method. European Journal of Political Economy. 2019. № 50 (1). P. 22-36.

\section{Information about authors:} Nepomnyashchyy O. M., Doctor of Science in Public Administration, Professor, Interregional Academy of Personnel Management 2, Frometivska Str., Kyiv, 03039, Ukraine

Diegtiar O. A.,

Doctor of Science in Public Administration, Associate Professor, Professor of the Department of Management and Public Administration O. M. Beketov National University of Urban Economy in Kharkiv 17, Marshal Bazhanov Str., Kharkiv, 61002, Ukraine 